\title{
Use of docosahexaenoic acid for lamb diet
}

\author{
Maria Júlia Pereira de Araújo ${ }^{1}$; Erica Beatriz Schultz ${ }^{2 *}$; Thauane Ariel Valadares de Jesus ${ }^{3}$; Marina Elizabeth \\ Barbosa Andrade ${ }^{4}$; Luciana Melo Sousa ${ }^{5}$; Gilberto de Lima Macedo Júnior ${ }^{6}$
}

DOI: https://doi.org/10.35699/2447-6218.2020.20203

\begin{abstract}
The purpose of this study was to evaluate the effects of docosahexaenoic acid in the concentrated acid on intake, digestibility, metabolic profile and ingestive behavior of lambs diets. Five crossbred Dorper x Santa Inês lambs with initial age and body weight average of six months and $33 \mathrm{~kg}$, respectively, were used in the trial. The animals were assigned into a $5 \times 5$ Latin square design and they received one of the following treatments: $0,1.5,3,4.5$ and $6 \%$ of microalgal product (Aurantiochytrium limacinum algae) or ALL-G Rich ${ }^{\circledR}$ in the concentrate. The diets were composed of corn silage and concentrate offered twice daily. During the experimental period, feed, water, feces, blood, and urine were sampled to calculate the intake and digestibility and to characterize the metabolic profile. The ingestive behavior was measured during 24 hours on the last day each experimental period. The time spent on feeding, ruminating and idle activities was measured. Regression analyses were performed considering $5 \%$ of significance. There were no difference on nutrients intake, digestibility, and ingestive behavior with the inclusion of ALL-G Rich ${ }^{\circledR}$ in the diet $(\mathrm{p}>0.05)$. There was a significant effect on serum concentrations of cholesterol, low density lipoprotein, alkaline phosphatase and gammaglutamyl transferase, however, all metabolites remained within the range recommended for the animal category. Thus, ALL-G Rich ${ }^{\circledR}$ can be used up to $6 \%$ in the concentrate, on dry matter basis, of lambs diet without affect intake, digestibility, metabolic profile, and ingestive behavior.
\end{abstract}

Keywords: Digestibility. Intake. Lipids.

\section{Uso do ácido docosahexaenóico na dieta para cordeiros}

\section{Resumo}

A proposta da pesquisa foi avaliar o efeito da inclusão de ácido docosahexaenóico no concentrado da dieta de cordeiros sobre o consumo, digestibilidade, perfil metabólico e comportamento ingestivo. Foram utilizadas cinco borregas mestiças (Dorper x Santa Inês) com média de 6 meses de idade e $33 \mathrm{~kg}$. Os animais foram distribuídos em delineamento quadrado latino $5 \times 5$ sendo os tratamentos: 0; 1,5; 3,0; 4,5 e 6\% de ALL-G Rich ${ }^{\circledR}$ no concentrado. As dietas foram compostas de silagem de milho e concentrado ofertadas duas vezes ao dia. Durante os períodos de avaliação foram mensurados e amostrados os alimento, água, fezes, sangue e urina. A partir dessas amostras foram calculados o consumo e digestibilidade. O comportamento ingestivo foi realizado durante 24 horas no último dia cada período experimental, mensurando o tempo gastos nas atividades de alimentação, ruminação e ócio. Análises de regressão

${ }^{1}$ Universidade Federal de Uberlândia. Uberlandia, MG. Brasil.

https://orcid.org/0000-0002-7730-5828

${ }^{2}$ Universidade Federal Rural do Rio de Janeiro. Rio de Janeiro, RJ. Brasil.

https://orcid.org/0000-0003-1916-2117

${ }^{3}$ Universidade Federal de Uberlândia. Uberlandia, MG. Brasil.

https://orcid.org/0000-0003-3127-7697

${ }^{4}$ Universidade Estadual Paulista. Jaboticabal, SP. Brasil.

https://orcid.org/0000-0003-3713-6377

${ }^{5}$ Universidade Estadual Paulista. Jaboticabal, SP. Brasil.

https://orcid.org/0000-0003-1016-8248

${ }^{6}$ Universidade Federal de Uberlândia. Uberlandia, MG. Brasil.

https://orcid.org/0000-0001-5781-7917

*Autor para correspondência: ericabeatrizschultz@gmail.com

Recebido para publicação em 17 de Abril de 2020. Aceito para publicação 25 de Agosto de 2020

e-ISSN: 2447-6218 / ISSN: 2447-6218 / (C) 2009, Universidade Federal de Minas Gerais, Todos os direitos reservados. 
foram utilizadas considerando 5\% de significância. Não houve efeito significativo diante do consumo e digestibilidade de matéria seca e dos nutrientes, tal como no comportamento ingestivo com a crescente inclusão de ALL-G Rich ${ }^{\circledR}$ na dieta. Houve efeito significativo para as concentrações séricas de colesterol, lipoproteína de baixa densidade, fosfatase alcalina e gamma glutamil transferase, porém todos os metabolitos mantiveram-se dentre da faixa recomendada para categoria. Portanto, a ALL-G Rich ${ }^{\circledR}$ pode ser utilizada até $6 \%$ na matéria seca do concentrado em dietas de cordeiras sem afetar o consumo, digestibilidade, o perfil metabólico e o comportamento ingestivo.

Palavras-chave: Consumo. Digestibilidade. Lipídeos.

\section{Introduction}

Lipids in the feed are energy source that decreases increment caloric, improves energy efficiency, and absorption of vitamins. The importance of lipids is related to the fatty acid profile, where saturated fatty acids lack double bonds and unsaturated fatty acids have at least one double bond. Also, fatty acids can be divided according to requirement and availability as essential and nonessential fatty acids (Palmiquist \& Mattos, 2011).

As examples of essential fatty acids, linoleic (omega-6) and linolenic (omega-3) acids are encountered mainly in fish oil, canola, linseed, soy, and algae, which has attracted attention for human health because of the decrease in obesity, cardiovascular disease, and increase in immunity (Calder, 2014). Also reported by Stark et al. (2016) that animal producers enriched with omega-3 long-chain polyunsaturated fatty acids (LCPUFA), eicosapentaenoic acid (EPA, 20:5n-3) and docosahexaenoic acid (DHA, 22:6n-3) have been associated with a decreased risk of chronic disease, in particular cardiovascular mortality and cognitive decline.

Conventionally, in ruminant nutrition is used 1 to $5 \%$ of lipids in the diet because more than $6 \%$ can reduce microorganism access to fiber and exceed hydrolyze capacity, reducing intake and digestibility of the feed (Palmquist \& Jenkis, 1980). A ruminant particularity is the biohydrogenation process in the rumen, which converts unsaturated to saturated fatty acids. Thus, the offered unsaturated source will be absorbed as saturated fatty acids in the intestine (Church, 1993). The exceptions that escape from this process is the polyunsaturated fatty acids (PUFA) as docosahexaenoic (omega-3) and eicosapentaenoic (omega-3) acids that are absorbed at intestinal level (Ponnampalam et al., 2009).

Some studies using distinct sources of omega-3 in the ruminant feed showed a decrease in methane production, improvement in animal health, meat and milk fatty acids profile for human consumption without damage animal's performance (Boeckaert et al., 2008; Pirondini et al., 2015; Thanh et al., 2018). Therefore, considering the contribution for animals and human our hypothesis is that the inclusion of docosahexaenoic acid can alter intake, digestibility, ingestive behavior and the metabolic profile of lambs.

The aim of this research was to evaluated the effect of inclusion of docosahexaenoic acid on nutrient intake, ingestive behavior, digestibility and metabolic profile of lambs.

\section{Material and Methods}

All procedures were conducted in accordance with the guidelines set out by the Brazilian College of Animal Experimentation in the Code of Practice for the Care and Use of Animal for Experimental Purposes, which were approved by the Ethics Committee on Use of Animal for Research (CEUA) of the Universidade Federal de Uberlândia under license number 183/2016.

Five lambs crossbred Dorper $x$ Santa Inês with an initial average age of $180 \pm 8$ days and body weight (BW) of $33.59 \pm 6.41 \mathrm{~kg}$ were assigned into a $5 \times 5$ Latin square design. The animals were housed in individual pens of $2 \mathrm{~m}^{2}$ with individual feeders and drinkers according to National Institute of Science and Technology (INCT). In total, the trial lasted 75 days, divided into five experimental periods of 15 days each one. An adaptation period was performed from the $1^{\text {st }}$ to $10^{\text {th }}$ day of each period and the collection period of feed, water, feces and urine sampling was performed from $10^{\text {th }}$ to $15^{\text {th }}$ day. Also, observation of ingestive behavior was performed from $14^{\text {th }}$ to $15^{\text {th }}$ day of each experimental period.

The diets were composed of corn silage, corn meal, soybean meal, and mineral premix. The treatments were characterized by the inclusion of $0,1.5,3,4.5$ and 6 $\%$ of the microalgal product (Aurantiochytrium limacinum algae) or ALL-G Rich ${ }^{\circledR}$ in the concentrate. The ALL-G Rich ${ }^{\circledR}$ composition are showed in Table 1 .

The ration was formulated according to Nutrient Requirements of Small Ruminants (NRC, 2007) for an average daily gain of $200 \mathrm{~g}$. Also, the diets were composed of $30 \%$ of roughage and $70 \%$ of concentrate. The concentrate composition and chemical composition of the experimental diets are showed in Table 2. 
Table 1 - ALL-G Rich ${ }^{\circledR}$ chemical composition.

\begin{tabular}{cccc}
\hline Item $^{*}$ & Value & Item $^{*}$ & Value \\
\hline Ethereal extract (\%) & 50 & Glycerol (\%) & 3.81 \\
Carbohydrates (\%) & 24.88 & Monoglycerides (\%) & $<1.0$ \\
Crude Protein (\%) & 19.22 & Triglycerides (\%) & 85.80 \\
Diglycerides (\%) & 4.69 & Docosahexaenoic acid (\%) & 27.20 \\
\hline
\end{tabular}

*The data were provided by Alltech ${ }^{\circledR}$.

The silage and concentrate were weighted and offered twice a day ( $08 \mathrm{~h} 00 \mathrm{~min}$ and $16 \mathrm{~h} 00 \mathrm{~min}$ ) as total mixed ration (TMR). The amount of supplied feed was corrected to generate $10 \%$ of leftovers in the dry matter basis. To adjust the amount of provided ration, the animals were weighted in the first and last day of each experimental period. In each experimental period, samples of feed and leftovers were collected daily and stored in plastic bags at $-20^{\circ} \mathrm{C}$. Also, the amount of total feces was weighted and sampled daily in each experimental period and stored in plastic bags at $-20^{\circ} \mathrm{C}$.

Table 2 - The concentrate and chemical compositions of the experimental diets.

\begin{tabular}{cccccc}
\hline & \multicolumn{5}{c}{ ALL G-Rich ${ }^{\circledR}$ (\%) } \\
\hline Item & $\mathbf{0}$ & $\mathbf{1 . 5}$ & $\mathbf{3}$ & $\mathbf{4 . 5}$ & $\mathbf{6}$ \\
\hline Corn meal & 67.35 & 66.25 & 65.2 & 64.1 & 63 \\
Soybean meal & 30.45 & 30.05 & 29.6 & 29.2 & 28.8 \\
ALL-G Rich ${ }^{\circledR}$ & 0 & 1.5 & 3 & 4.5 & 6 \\
Mineral premix & 2 & 2 & 2 & 2 & 2 \\
Adsorbent & 0.2 & 0.2 & 0.2 & 0.2 & 0.2 \\
\hline Item & & & ALL G-Rich & (\%) & \\
\hline Crude protein (\%) & $\mathbf{0}$ & $\mathbf{1 . 5}$ & $\mathbf{3}$ & $\mathbf{4 . 5}$ & $\mathbf{6}$ \\
\hline Neutral detergent fiber (\%) & 16.55 & 16.55 & 16.55 & 16.55 & 16.55 \\
Acid detergent fiber (\%) & 19.94 & 19.76 & 20.18 & 19.78 & 20.13 \\
Ether extract (\%) & 11.08 & 11.43 & 11.34 & 11.09 & 11.33 \\
Total digestive nutrients (\%) & 1.60 & 1.65 & 1.67 & 1.69 & 1.79 \\
\hline
\end{tabular}

An amount of 6 liter of water per animal in a bucket with capacity of 8 liter was offered once a day at $08 \mathrm{~h} 00 \mathrm{~min}$. Meanwhile, one reference bucket of same size with 6 liter of water was used to measure the daily evaporation, thus, the water intake was daily measured. Also, urine production were measured through graduated test tube with precision of $20 \mathrm{~mL}$ in each experimental period.

Samples of feeds, leftovers and feces were analyzed to determine the concentration of dry matter (DM), ether extract (EE) and crude protein (CP) (AOAC, 1990). The concentration of neutral detergent fiber (NDF) and acid detergent fiber (ADF) were based on the description of Van Soest et al. (1991).
The DM, EE, NDF, and ADF intake were calculated by difference between offered feed and leftovers. The water intake was determined by difference among offered, leftover, and evaporation. The DM and NDF digestibility was estimated by difference among intake and feces divided by intake. After quantification of urine volume, a sample of $100 \mathrm{~mL}$ was collected to measure the urine density, using Megabrix ${ }^{\circledR}$ manual refractometer.

Blood samples were collected on $11^{\text {th }}, 13^{\text {th }}$ and $15^{\text {th }}$ day of each experimental period before first feeding by jugular vein puncture with auxiliary vacuntainner tubes without anticoagulant. After collection, the blood samples were immediately centrifuged at $2.700 \times \mathrm{g}$ for $20 \mathrm{~min}$. The plasma samples were pipetted and frozen at $-18^{\circ} \mathrm{C}$ for later analysis according to Russell et al. (2007) for total protein, albulmin, globulin, uric acid, urea, creatinine, cholesterol, triglycerides, low density lipoprotein, high 
Araújo, M. J. P. et al.

density lipoprotein, very low density lipoprotein, aspartate aminotransferase, gammaglutamyl transferase, and alkaline phosphatase using a commercial kit from Lab Test ${ }^{\circledR}$ in an automated biochemical analyzer (Bioplus ${ }^{\circledR} 2000$ ).

Feeding behavior such as eating, ruminating and idling time of all ewes were evaluated on $14^{\text {th }}$ to $15^{\text {th }}$ day

The statistical model was:

$$
Y_{i j k l}=\mu+t_{i}+P_{j}+A_{k}+e_{i j k l} \text {; }
$$

where: $Y_{i j k l}=$ observation $i j k l ; t_{i}=$ treatment fixed effect $i ; P_{j}=$ period fixed effect $j ; A_{k}=$ animal random effect $k ; e_{i j k l}=$ random error $l$. Comparisons between ALL-G Rich ${ }^{\circledR}$ levels in the diets were conducted by the sum decomposition of squares in orthogonal contrasts to linear and quadratic effects with $5 \%$ of significance (p $<0.05$ ).

\section{Results and Discussion}

Intake of DM, DM in relation to body weight, EE, $\mathrm{NDF}$, and ADF were not different across the treatments ( $p>0.05$ ) (Table 3 ). The ruminant intake is regulated by a compilation of factors, for instance, physical (i.e. fill ruminal), chemical (i.e. satiety), and psychogenic (i.e. palatability) associated with diet composition (Mertens, 1994). Furthermore, inclusion of algae percentages showed no differences on chemical profile of the diets (isoenergetic and isoproteic) (Table 2), leading to equivalent nutrient intake between treatments.

Another fact related with no change in nutrients intake can be the percentage of ether extract in the diets. According to Palmquist e Jenkis (1980) the maximum amount of lipids in the diet should be between $5 \%$ to avoid negative effects on ruminal microbiota. Therefore, in our experimental diets with $1.79 \%$ maximum of EE, there was no influence on nutrient intake among treatments (Table 3). As reported by Thanh et al. (2018), where sunflower and fish oil were used as sources of docosahexaenoic, there was no difference in the nutrients intake because the maximum percentage ethereal extract was $4.67 \%$, no exceeding the recommendations.

In relation to lipid composition, the algae product is rich in polyunsaturated fatty acids (PUFAS), as docosahexaenoic acid, which according to Altomonte et al. (2018) may have toxic effects on the ruminal microflora. However, we emphasize that given the low inclusion of ALL G-Rich ${ }^{\circledR}$ up to $6 \%$ in the concentrate, it did not change intake and nutrient digestibility (Table 3 ).

The average values of DM and NDF intake were 1.27 and $0.594 \mathrm{~kg} . \mathrm{d}^{-1}$, respectively, corresponding to 3.78 and $1.76 \%$ of body weight, respectively. The average of NDF and NDF in relation to BW were higher than reported by Mertens (1997), which suggest that NDF intake can reach $1.20 \%$ of $\mathrm{BW}$, demonstrating that in of each experimental period in every five minutes during 24 hours, according to methodology proposed by Fischer et al. (1998). The chewing time was calculated by sum of eating and rumination times. The eating, rumination and chewing efficiencies were calculated by dividing the intake of dry matter by the total eating, rumination and chewing times.

this study intake was not restricted by rumen fill. However, the average of DMI (1.0 to $1.30 \mathrm{~kg}$ day) and DMI in relation to $\mathrm{BW}$ (2.97 to $3.87 \%$ of $\mathrm{BW}$ ) are within the recommended for lambs according to NRC (2007). Thus, we can conclude that despite NDF intake, \%NDF of BW was beyond suggested, do not observing intake restriction.

According to Forbes (1996), intake regulator factors operate in an integrated process, therefore, DM intake was not limited by physical effects because diet digestibility showed an average of $83.45 \%$. Diets with this percentage of digestibility is considered highly fermentable and with high production of volatile fatty acids, leading consequently to the interaction of physical and osmotic intake controls. This control interaction happened in all treatments, therefore, increasing ALL G-Rich ${ }^{\circledR}$ in the concentrate did not change DM and NDF digestibility (p >0.05) (Table 3).

The docosahexaenoic intake in the treatments was estimated as $0,1.5,3,4,5$ and, $6 \%$ of ALL G-Rich ${ }^{\circledR}$, being 3.78, 7.23, 10.96 and $13.70 \mathrm{~g} \mathrm{~d}^{-1}$, respectively. Thus, ALL G-Rich ${ }^{\circledR}$ up to $6 \%$ with $13.70 \mathrm{~g} \mathrm{~d}^{-1}$ as a source of docosahexaenoic was used without change the nutrients intake and digestibility. This response opposes that reported by Palmquist e Mattos (2011) and Borghi (2018), it's because these studies increased algae and lipids more than our used, nearly $6 \%$, thus, when we increase PUFA sources in the ruminant diet the DM and NDF digestibility decrease due to toxicity to ruminal microbiota, hampering fiber degradation. The results of these studies show that the unsaturated lipid can damage rumen, reducing DM and DND. However, the levels included in our study were not detrimental to the dry matter intake and digestibility.

Similarly to nutrients intake, there were no significant differences among treatments for water intake and water losses ( $p>0.05$ ) (Table 4). The water intake and urine density in relation dry matter intake did not change ( $p>0.05)$ (Table 4). The average of water intake and urine volume was 4.97 and $1.51 \mathrm{ld} \mathrm{d}^{-1}$, respectively. The water intake was $27.11 \%$ higher to the calculated by the equation proposed by Forbes (1968), which NRC (2007) recommends. However, this equation is a general requirement for all ewes class, and our study used growing lambs. Thus, it is still necessary specific equations to all small ruminants classes. The response of water is also related to diet profile, which was composed of $70 \%$ of 
Araújo, M. J. P. et al.

concentrate containing little humidity, increasing intake requirements of water. Urine volume and urine density are within the range describe by Reece (2006) of 100 to $400 \mathrm{ml}$ per $10 \mathrm{~kg}$ of BW and 1.015 to $1.045 \mathrm{~g} \mathrm{ml}^{-1}$ (Carvalho, 2008).

Table 3 - Digestibility and nutrients intake of lambs with levels ALL G-Rich ${ }^{\circledR}$ in the concentrate.

\begin{tabular}{ccccccccc}
\hline & \multicolumn{4}{c}{ ALL G-Rich ${ }^{\circledR}$} & (\%) & \multicolumn{3}{c}{ p-values } \\
\hline Item & $\mathbf{0}$ & $\mathbf{1 . 5}$ & $\mathbf{3}$ & $\mathbf{4 . 5}$ & $\mathbf{6}$ & SEM & L & Q \\
\hline Dry matter intake $\left(\mathrm{kg} \mathrm{d}^{-1}\right)$ & 1.35 & 1.27 & 1.28 & 1.27 & 1.20 & 0.053 & 0.157 & 0.992 \\
Dry matter intake $\left(\mathrm{kg} \mathrm{d}^{-1} \mathrm{BW}\right)$ & 3.37 & 3.14 & 3.26 & 3.17 & 3.01 & 0.094 & 0.197 & 0.915 \\
Ethereal extract intake $\left(\mathrm{kg} \mathrm{d}^{-1}\right)$ & 0.032 & 0.031 & 0.031 & 0.030 & 0.032 & 0.001 & 0.958 & 0.234 \\
Neutral detergent fiber intake $\left(\mathrm{kg} \mathrm{d}^{-1}\right)$ & 0.591 & 0.48 & 0.591 & 0.511 & 0.573 & 0.026 & 0.974 & 0.303 \\
Acid detergent fiber intake $\left(\mathrm{kg} \mathrm{d}^{-1}\right)$ & 0.204 & 0.186 & 0.231 & 0.21 & 0.219 & 0.012 & 0.504 & 0.902 \\
Dry matter digestibility (\%) & 83.39 & 83.53 & 81.31 & 84.45 & 84.06 & 0,009 & 0.399 & 0.635 \\
Neutral detergent fiber digestibility (\%) & 65 & 60.79 & 67.29 & 68.14 & 62.14 & 2.735 & 0.625 & 0.982 \\
\hline
\end{tabular}

BW: body weight; SEM: standard error of the mean; L: linear effect; Q: quadratic effect.

Table 4 - Intake and loss of water of lambs with levels ALL G-Rich ${ }^{\circledR}$ in the concentrate.

\begin{tabular}{ccccccccc}
\hline & \multicolumn{3}{c}{ ALL G-Rich $^{\circledR}$ (\% of concentrate) } & & \multicolumn{3}{c}{ p-values } \\
\hline Item & $\mathbf{0}$ & $\mathbf{1 . 5}$ & $\mathbf{3}$ & $\mathbf{4 . 5}$ & $\mathbf{6}$ & SEM & L & $\mathbf{Q}$ \\
\hline Water intake $\left(\mathrm{l} \mathrm{d}^{-1}\right)$ & 4.69 & 5.28 & 5.16 & 5.11 & 4.61 & 0.222 & 0.663 & 0.149 \\
Water / Dry matter intake $\left(1 \mathrm{~kg} \mathrm{~d}^{-1}\right)$ & 3.43 & 4.65 & 4.2 & 4.19 & 4.13 & 0.303 & 0.386 & 0.084 \\
Urine volume $\left(\mathrm{l} \mathrm{d}^{-1}\right)$ & 1.528 & 1.523 & 1.737 & 1.292 & 1.474 & 0.188 & 0.771 & 0.744 \\
Urine density $\left(\mathrm{g} \mathrm{ml}^{-1}\right)$ & 1.022 & 1.021 & 1.014 & 1.025 & 1.020 & 0.002 & 0.874 & 0.697 \\
\hline
\end{tabular}

SEM: standard error of the mean; L: linear effect; Q: quadratic effect.

In relation to metabolic profile, there was no significant differences on total protein, albumin, globulin, uric acid, urea, creatinine, triglycerides, very low density lipoprotein and high-density lipoprotein as increase docosahexaenoic increased in the diet $(p>0.05)$ (Table 5). However, cholesterol and low-density lipoprotein showed a significant $(\mathrm{p}<0.05)$ quadratic behavior as increased feeding levels of ALL G-Rich ${ }^{\circledR}$ were added in the concentrate (Table 5). All energy and protein metabolites values are between reference values.

The metabolic profile is used to access and prevent metabolic and nutritional disorders in animal production, mainly, when unusual products are included in the diet. Protein metabolites: total protein, albumin, globulin, uric acid, urea, and creatinine are positive correlated with dietary protein intake, rumen degradability, and dietary amino acid composition (Puppel e Kuczynska, 2016). As the diets were formulated to be isoprotein, there was no difference between treatments for concentration of protein metabolites.

The diet balance is verified through the urea concentration. According to Wittwer (2000), blood urea reflects the ammonia generated in the rumen by the degradation of the nitrogen compounds that were not converted into microbial protein. Thus, ammonia crosses the rumen wall where it is transformed into urea in the liver with high energy expenditure. Subsequently, this urea can be eliminated by urinary excretion or milk (in the case of lactating animals), and return to the rumen via salivation or perfusion in the ruminal wall.

The urea values remained within the recommended range with inclusion of ALL G-Rich ${ }^{\circledR}$. Treatments did not affect the synergism of the degradation of nitrogen and carbohydrate sources in the ruminal environment, leading to no ammonia escape and subsequent no unnecessary energy expenditure for the animals. Therefore, all protein metabolites remained within the normal range of protein metabolism as recommended by Varanis (2018) for growing lambs.

Among energetic metabolites, there were reduction in cholesterol and low-density lipoprotein concentrations up to $4 \%$, and an increase in concentration with $6 \%$ of ALL G-Rich ${ }^{\circledR}$. 
Araújo, M. J. P. et al.

Table 5 - Energetic and protein metabolites of lambs with levels ALL G-Rich ${ }^{\circledR}$ in the concentrate.

\begin{tabular}{cccccccccc}
\hline & \multicolumn{1}{c}{ ALL G-Rich ${ }^{\circledR}$ (\%) } & & & \multicolumn{2}{c}{ p-value } \\
\hline Item & $\mathbf{0}$ & $\mathbf{1 . 5}$ & $\mathbf{3}$ & $\mathbf{4 . 5}$ & $\mathbf{6}$ & SEM & RV & L & Q \\
\hline Total protein (mg dL)* & 7.44 & 7.98 & 8.34 & 7.06 & 8.2 & 0.021 & 3.1 to 11.4 & 0.258 & 0.893 \\
Albulmin (mg dL)* & 3.49 & 3.85 & 3.29 & 3.18 & 2.86 & 0.001 & 1.12 to 5.38 & 0.398 & 0.748 \\
Globulin (mg dL)** & 3.94 & 4.45 & 5.04 & 3.88 & 5.34 & 0.148 & 3.5 to 5.7 & 0.473 & 0.698 \\
Uric acid (mg dL)* & 0.48 & 0.46 & 0.5 & 0.44 & 0.48 & 0.108 & 0 to 2.9 & 0.597 & 0.259 \\
Urea (mg dL)* & 48.56 & 46.46 & 57.76 & 46.78 & 48.44 & 0.225 & 12.8 to100 & 0.148 & 0.123 \\
Creatinine (mg dL)* & 0.74 & 0.72 & 0.74 & 0.72 & 0.74 & 0.001 & 0.40 to 1.80 & 0.163 & 0.543 \\
Cholesterol (mg dL) ${ }^{1 *}$ & 52.56 & 51.76 & 53.5 & 49.22 & 55.78 & 0.196 & 15 to 139.9 & 0.362 & 0.042 \\
Triglycerides (mg dL)* & 25.82 & 24.78 & 21.92 & 19.56 & 20.82 & 0.207 & 5 to 78 & 0.589 & 0.969 \\
Low density lipoprotein (mg dL)*2 & 21.22 & 11.12 & 11.95 & 8.12 & 14.85 & 0.366 & 0.80 to 83.36 & 0.093 & 0.001 \\
High density lipoprotein (mg dL)* & 37.56 & 41.64 & 40.04 & 37.18 & 36.76 & 0.284 & 13 to 79 & 0.111 & 0.473 \\
Very low density lipoprotein (mg dL) $*$ & 5.16 & 4.95 & 4.38 & 3.91 & 4.16 & 0.189 & 1 to17.4 & 0.589 & 0.969 \\
\hline
\end{tabular}

*RV: reference value accord to Varanis, (2018); **RV: reference value accord to Kaneko, (2008); SEM: standard error of the mean; L: linear effect; $\mathrm{Q}$ : quadratic effect. ${ }^{1} \mathrm{Y}=53.02-1.39 \mathrm{X}+0.27 \mathrm{X}^{2} ; \mathrm{R}^{2}=30.06 \% ;{ }^{2} \mathrm{Y}=20.74-6,56 \mathrm{X}+0.92 \mathrm{X}^{2} ; \mathrm{R}^{2}=86.20 \%$

The ALL G-Rich ${ }^{\circledR}$ is rich in PUFA's, which is biohydrogenated in the rumen. When the docosahexaenoic acid is biohydrogenated, it is converted to a long saturated long chain fatty acid, the docosonaic acid (C 22:0) (Aldai et al., 2018). Thus, the increase in serum cholesterol concentration may occur due to the high demand for digestion, absorption, and transport of long-chain fatty acids (Freitas Júnior et al., 2010).

In this context, we call attention to the reduction of low-density lipoprotein concentration (LDL) up to 4\% of ALL G-Rich ${ }^{\circledR}$ in the diet, the LDL acts on the transport of cholesterol from the liver to the tissues. The increase in cholesterol is indicative of an increase in energy metabolism in the liver (NDLOVU et al., 2007).
The reduction of LDL concentration may occurred due to the greater use of fat from ALL G-Rich ${ }^{\circledR}$ in the diet as energy source, which leaded to less need for fat mobilization from the liver to the tissues. This is also favorable because according to Brás et al. (2014) it leads to a lower probability of developing health problems such as cardiovascular diseases. It is worth mentioning that, although there were differences in cholesterol and LDL between treatments, all energy metabolites were within recommended range to the animal category according to Varanis (2018).

In relation to hepatic metabolites, there were a quadratic and linear effect for alkaline phosphatase and gammaglutamyl transferase $(\mathrm{p}<0.05)$, respectively. However, means values of aspartate aminotransferase were not affected by the increase DHA in the diet.

Table 6 - Hepatic metabolite of lambs with levels ALL G-Rich ${ }^{\circledR}$ in the concentrate.

\begin{tabular}{|c|c|c|c|c|c|c|c|c|c|}
\hline \multicolumn{8}{|c|}{ ALL G-Rich ${ }^{\circledR}(\%)$} & \multicolumn{2}{|c|}{ p-value } \\
\hline Item & 0 & 1.5 & 3 & 4.5 & 6 & SEM & $\mathrm{RV}^{*}$ & $\mathbf{L}$ & Q \\
\hline Aspartate aminotransferase (U L) & 161.24 & 214.04 & 357.84 & 269.02 & 199.3 & 12,36 & 47 to 353.5 & 0.256 & 0.445 \\
\hline Alkaline phosphatase $(\mathrm{U} L)^{3}$ & 283.98 & 328.18 & 347.56 & 311.62 & 328.16 & 25,36 & 58 to 727.7 & 0.398 & 0.025 \\
\hline Gammaglutamyl transferase (U L) ${ }^{4}$ & 62.66 & 80.16 & 97.2 & 87.72 & 94.52 & 4,23 & 31 to 154 & 0.558 & 0.002 \\
\hline \multicolumn{10}{|c|}{$\begin{array}{l}\text { RVV: reference value according to Varanis, (2018); SEM: standard error of the mean; L: linear effect; Q: quadratic effect; }{ }^{3} \mathrm{Y}=289.73+25.86 \mathrm{X}- \\
3.51 \mathrm{X}^{2} ; \mathrm{R}^{2}=61.48 \% ;{ }^{4} \mathrm{Y}=70.19+4.75 \mathrm{X} ; \mathrm{R}^{2}=66.17 \% \text {. }\end{array}$} \\
\hline $\begin{array}{l}\text { According to Dallago et al } \\
\text { oncentrations of alkaline phosphata } \\
\text { ansferase and aspartate aminotra } \\
\text { hepatic injuries. When hepatic inj } \\
\text { cellular damage overflows the he }\end{array}$ & $\begin{array}{l}\text { o11), } \\
\text { gamma } \\
\text { rase ar } \\
\text { s happe }\end{array}$ & $\begin{array}{l}\text { elevated } \\
\text { glutamyl } \\
\text { e related } \\
\text { en, hepa- }\end{array}$ & & $\begin{array}{l}\text { eir ser } \\
\text { th inct } \\
\text { mainec } \\
\text { at ther }\end{array}$ & $\begin{array}{l}\text { conce } \\
\text { se DH } \\
\text { vithin } \\
\text { s no ri }\end{array}$ & $\begin{array}{l}\text { in th } \\
\text { eren } \\
\text { of int }\end{array}$ & $\begin{array}{l}\text { diet, all me } \\
\text { intervals } \mathrm{f} \\
\text { xication wh }\end{array}$ & $\begin{array}{l}\text { bolite } \\
\text { lamb }\end{array}$ & $\begin{array}{l}\text { patics } \\
\text { owing }\end{array}$ \\
\hline
\end{tabular}


Araújo, M. J. P. et al.

In relation to animal behavior, the time lambs spent in feeding, rumination, idle, and chewing as well as efficiency times of these activities were not different between treatments ( $p>0.05$ ) when added up to $6 \%$ of ALL G-Rich ${ }^{\circledR}$ in the concentrate (Table 7). Mean values of feeding, rumination, idle and chewing were 191.8, 349.4, 898.8 and $541.2 \mathrm{~min}^{-1}$, respectively.

The ingestive behavior is controled by several factors, for instance, nutrients intake, particle size and nutrients digestibility (Van Soest, 1994). We did not observed changes in this factors among treatments, thus, increased levels of ALL G-Rich ${ }^{\circledR}$ in the experimental diets did not change the time spent in feeding, rumination, idle and chewing activities, and consequently on their efficiency. We call attention to the value of ruminating time that was lower than showed by Van Soest (1994), which reports a time of 360 to $480 \mathrm{~min}^{\text {day }^{-1} \text { rumina- }}$ ting. However, the diet composition of this study had high proportion of soluble carbohydrates. The values of feeding, ruminating and idle activities of 3.19, 5.82 e $14.98 \mathrm{~h} \mathrm{day}^{1}$ were similar as those reported by Silva (2018) of 4.76, 5.98, $13.26 \mathrm{~h}^{\text {day }}{ }^{-1}$, respectively, using up to $4 \%$ algae meal in lamb diet.

Table 7 - Ingestive behavior of lambs with levels ALL G-Rich ${ }^{\circledR}$ in the concentrate.

\begin{tabular}{|c|c|c|c|c|c|c|c|c|}
\hline \multirow[b]{2}{*}{ Item } & \multicolumn{5}{|c|}{ ALL G-Rich ${ }^{\circledR}$ (\% of concentrate) } & \multirow[b]{2}{*}{ SEM } & \multicolumn{2}{|c|}{ p-values } \\
\hline & 0 & 1.5 & 3 & 4.5 & 6 & & $\mathbf{L}$ & $\mathbf{Q}$ \\
\hline Feeding time $\left(\operatorname{min~}^{-1}\right)$ & 187 & 188 & 197 & 195 & 192 & 6.524 & 0.712 & 0.627 \\
\hline Rumination time $\left(\operatorname{min~}^{-1}\right)$ & 347 & 352 & 351 & 368 & 329 & 8.804 & 0.761 & 0.375 \\
\hline Idle time $\left(\operatorname{min~}^{-1}\right)$ & 906 & 900 & 892 & 877 & 919 & 12.08 & 0.396 & 0.971 \\
\hline Chewing time $\left(\min \mathrm{d}^{-1}\right)$ & 534 & 540 & 548 & 563 & 521 & 12.08 & 0.760 & 0.368 \\
\hline Feeding efficiency $\left(\mathrm{g}\right.$ of $\mathrm{DM} \mathrm{min}^{-1}$ ) & 7.3 & 6.74 & 6.76 & 6.76 & 6.52 & 0.345 & 0.242 & 0.689 \\
\hline Rumination efficiency ( $\mathrm{g}$ of $\mathrm{DM} \mathrm{min}^{-1}$ ) & 3.96 & 3.6 & 3.69 & 3.53 & 3.68 & 0.162 & 0.460 & 0.452 \\
\hline Chewing efficiency ( $\mathrm{g}$ of $\mathrm{DM} \mathrm{min}^{-1}$ ) & 2.56 & 2.33 & 2.37 & 2.29 & 2.33 & 0.102 & 0.249 & 0.391 \\
\hline
\end{tabular}

SEM: standard error of the mean; L: linear effect; Q: quadratic effect.

\section{Conclusion}

The ALL-G RICH ${ }^{\circledR}$ is viable to use on diets for lambs in a level up to $6 \%$, which represents up to $13.70 \mathrm{~g} \mathrm{~d}^{-1}$ of docosahexaenoic acid intake. This percentage of inclu- sion do not affect ingestive behavior, digestibility, and nutrient intake, also, maintains metabolic profile within the recommended range for the animal category, increases cholesterol and reduces LDL concentration.

\section{References}

Aldai, N., P. Delmonte, S. Alves, R. J. B. Bessa, and J. Kramer. 2018. Evidence for the initial steps of DHA biohydrogenation by mixed ruminal microorganisms from sheep involves formation of conjugated fatty acids. J. Agric. Food Chem. 66: 842-855. Doi: https://doi.org/10.1021/acs. jafc.7b04563.

Altomonte, I., Salari, F., Licitra, R., \& Martini, M. 2018. Use of microalgae in ruminant nutrition and implications on milk quality-A review. Livestock science, 214: 25-35. Doi: https://doi.org/10.1016/j. livsci.2018.05.006.

Association of official analytical chemistry (AOAC). 1990. Official methods of analysis. 15.ed. Arlington: AOAC International, 1117p.

Boeckaert, C., Vlaeminck, B., Dijkstra, J., Issa-Zacharia, A., Van Nespen, T., Van Straalen, W., Fievez, V. 2008. Effect of dietary starch or micro algae supplementation on rumen fermentation and milk fatty acid composition of dairy cows. Journal of Dairy Science, 91(12): 4714-4727. Doi: https://doi.org/10.3168/jds.2008-1178.

Borghi, T.H. Farinha de algas marinhas (Schizochytrium sp.) na alimentação de cordeiros confinados: desempenho, digestibilidade e qualidade da carcaça e da carne. 2018. 113f. Tese (Doutorado em Zootecnia) - Faculdade de Ciências Agrárias e Veterinárias, Universidade Estadual Paulista.
Brás, P., Possenti, R. A., Bueno, M. S., Canova, E. B., Schammas, E. A. 2014. Avaliação nutricional de coprodutos da extração de óleos vegetais em dieta de ovinos. Boletim de Indústria Animal, 71(2), 160-175. Doi: https://doi.org/10.17523/bia.v71n2p160.

Calder, P. C. 2014. Very long chain omega-3 (n-3) fatty acids and human health. European journal of lipid science and technology, 116(10): 1280-1300. Doi: https://doi.org/10.1002/ejlt.201400025.

Carvalho, M. B. Semiologia do Sistema Urinário. In: FEITOSA, F.L. SemiologiaVeterinária. São Paulo: Roca, 2008. p. 389-409.

Church, D.C. Fisiologia digestiva y nutrición de los ruminantes. Zaragoza: Acríbia, 1993. 641p.

Dallago, B. S. L., McManus, C. M., Caldeira, D. F., Lopes, A. C., Paim, T. D. P., Franco, E., Louvandini, H. 2011. Performance and ruminal protozoa in lambs with chromium supplementation. Research in veterinary science, 90(2): 253-256. Doi: https://doi.org/10.1016/j. rvsc.2010.06.015.

Mertens, D. R. 1996. Methods in modelling feeding behaviour and intake in herbivores. In Annales de zootechnie (Vol. 45, pp. 153-164). 
Fischer, V., Deswysen, A. G., Dèspres, L., Dutilleul, P., Lobato, J. F. P. 1998. Padrões nictemerais do comportamento ingestivo de ovinos. Revista Brasileira de Zootecnia, 27(2):362-369.

Forbes, J. M. 1968. The water intake of ewes. British Journal of Nutrition, 22(1): 33-43. Doi: https://doi.org/10.1079/BJN19680006.

Forbes, J. M. 1996. Integration of regulatory signals controlling forage intake in ruminants. Journal of Animal Science, 74(12): 3029-3035. Doi: https://doi.org/10.2527/1996.74123029x.

Freitas Júnior, J. E. D., Rennó, F. P., Silva, L. F. P., Gandra, J. R., Maturana Filho, M., Foditsch, C., \& Venturelli, B. C. 2010. Parâmetros sanguíneos de vacas leiteiras suplementadas com diferentes fontes de gordura. Ciência Rural, 40(4): 950-956. Doi: https://doi.org/10.1590/ S0103-84782010005000039.

Kaneko, J.J.; Harvey, J.W.; Bruss, M.L. Clinical biochemistry of domestic animals.6. ed. San Diego: Academic Press, 2008. 916p.

Mertens, D. R., Regulation of forage intake. In: FAHEY, G. C. (Ed.) Forage quality, evaluation, and utilization. Madison: American Society Agronomy. p.450-493, 1994.

Mertens, D. R. 1997. Creating a system for meeting the fiber requirements of dairy cows. Journal of dairy science, 80(7): 1463-1481. Doi: https:// doi.org/10.3168/jds.S0022-0302(97)76075-2.

National research council (NRC). Nutrient Requeriments of Small Ruminants. Washington, DC, USA: National Academy Press, 2007. 362p.

Ndlovu, T., Chimonyo, M., Okoh, A. I., Muchenje, V., Dzama, K., Raats, J. G. 2007. Assessing the nutritional status of beef cattle: current practices and future prospects. African Journal of Biotechnology, 6(24).

Palmquist, D. L., \& Jenkins, T. C. 1980. Fat in lactation rations. Journal of dairy science, 63(1): 1-14. Doi: https://doi.org/10.3168/jds.S00220302(80)82881-5.

Palmquist D. L.; Mattos, W. R. S. Metabolismo de lipídios. In: Berchielli, T. T.; Pires, A. V.; Oliveira, S. G. (Ed.). Nutrição de ruminantes. 2. ed. Jaboticabal: Funep, 2011. p. 299-322.

Ponnampalam, E. N., Hopkins, D. L., Butler, K. L., Dunshea, F. R., Sinclair, A. J., \& Warner, R. D. 2009. Polyunsaturated fats in meat from Merino, first-and second-cross sheep slaughtered as yearlings. Meat Science, 83(2): 314-319. Doi: https://doi.org/10.1016/j. meatsci.2009.05.018.

Pirondini, M., Colombini, S., Mele, M., Malagutti, L., Rapetti, L., Galassi, G., Crovetto, G. M. 2015. Effect of dietary starch concentration and fish oil supplementation on milk yield and composition, diet digestibility, and methane emissions in lactating dairy cows. Journal of dairy science, 98(1): 357-372. Doi: https://doi.org/10.3168/jds.2014-8092.
Puppel, K., Kuczyńska, B. 2016. Metabolic profiles of cow's blood; a review. Journal of the Science of Food and Agriculture, 96(13): 4321-4328. Doi: https://doi.org/10.1002/jsfa.7779.

Reece, W. O. Função Renal nos Mamíferos. In: Reece, W. O. DUKES Fisiologia dos animais domésticos. 12. ed. Rio de Janeiro: Guanabara Koogan, 2006. p. 68-96.

Russell, K. E., \& Roussel, A. J. 2007. Evaluation of the ruminant serum chemistry profile. Veterinary Clinics of North America: Food Animal Practice, 23(3): 403-426. Doi: https://doi.org/10.1016/j. cvfa.2007.07.003.

Silva, L.G. Farinha de algas marinhas (Schizochytrium sp.) e vitamina E na alimentação de cordeiros confinados. 2018. 85p. Dissertação (Mestrado em Zootecnia) - Faculdade de Ciências Agrárias e Veterinárias, Universidade Estadual Paulista, 2018.

Stark, K. D., Van Elswyk, M. E., Higgins, M. R., Weatherford, C. A., \& Salem Jr, N. (2016). Global survey of the omega-3 fatty acids, docosahexaenoic acid and eicosapentaenoic acid in the blood stream of healthy adults. Progress in lipid research, 63: 132-152. Doi: https:// doi.org/10.1016/j.plipres.2016.05.001.

Thanh, L. P., Phakachoed, N., Meeprom, C., Suksombat, W. 2018. Replacement of fish oil for sunflower oil in growing goat diet induces shift of ruminal fermentation and fatty acid concentration without affecting intake and digestion. Small ruminant research, 165: 71-78. Doi: https://doi.org/10.1016/j.smallrumres.2018.05.015.

Van Soest, P.J. Nutritional Ecology of the Ruminant. 2.ed. London: Constock Publishing Associates, USA, 1994, 476 p.

Van Soest, P. V., Robertson, J. B., \& Lewis, B. A. 1991. Methods for dietary fiber, neutral detergent fiber, and nonstarch polysaccharides in relation to animal nutrition. Journal of dairy science, 74(10): 35833597. Doi: https://doi.org/10.3168/jds.S0022-0302(91)78551-2.

Varanis, L.F.M. Prospecção de metabólitos sanguíneos referenciais para ovinos em distintas categorias. 2018. 45f. Dissertação (Mestrado em Ciências Veterinárias) - Faculdade de Medicina Veterinária, Universidade Federal de Uberlândia, Uberlândia, 2018.

Wittwer, F. Diagnóstico dos desequilíbrios metabólicos de energia em rebanhos bovinos. In: Gonzalez, F.H.D.; Barcelos, J.O.; Patinõ, H.O.; Ribeiro, L.A. Perfil metabólico em ruminantes. Seu uso em nutrição e doenças nutricionais. Porto Alegre: UFRGS, 2000. p.9-22. 